\title{
Subglacial chemical erosion: seasonal variations in solute provenance, Haut Glacier d'Arolla, Valais, Switzerland
}

\author{
G. H. BROWN, \\ Centre for Glaciology, Institute of Earth Studies, University of Wales, Aberystwyth, Dyfed Sr23 3DB, Wales \\ M. SHARP, \\ Department of Earth and Atmospheric Sciences, University of Alberta, Edmonton, Alberta T6G 2E3, Canada \\ M. TRANTER \\ Department of Geography, University of Bristol, Bristol BS8 1SS, England
}

\begin{abstract}
This paper determines the provenance of solute in bulk meltwaters draining Haut Glacier d'Arolla, Valais, Switzerland, during the 1989 ablation season. Dissolved species are partitioned into components derived from sea salt, acid aerosol, dissolution of atmospheric $\mathrm{CO}_{2}$, and lithogenic sources, namely carbonates, sulphides and aluminosilicates. A major conclusion is that trace geochemically reactive minerals in the bedrock contribute the bulk of the solute found in runoff. Seasonal changes in solute provenance and in the dominant chemical weathering process are observed. Whereas the chemical weathering of aluminosilicate minerals by carbonation reactions remains relatively constant during the ablation season, the chemical erosion of carbonates shows distinct seasonal variations, reflecting changes in the nature of the subglacial drainage system. Subglacial drainage structure and bedrock type are key controls on the extent of subglacial chemical weathering.
\end{abstract}

\section{INTRODUCTION}

The traditional view that chemical erosion is least intense in glacial environments, founded on the notion that low temperatures inhibit chemical weathering processes, has been overturned by numerous studies since 1970 (see Brown and others, 1994; Sharp and others, 1995). The traditional view failed to account for the importance of acid snowmelt, and underplayed the role of moisture availability, the freshly ground character of the rock flour, and geochemically reactive trace minerals. Regarding the extent to which water acts as a reagent, catalyst and carrier in chemical weathering reactions, its abundance should be crucial to the rate of chemical weathering reactions (Reynolds and Johnson, 1972; Lerman, 1979). Therefore, the seasonality of runoff in glaciated catchments is of especial significance, since the rate of dissolution is inversely related to time-dependent solute concentration, and hence the meltwater flushing rate (Lerman, 1979; Brown and others, in press).

A major focus of geochemical research in active glaciated regions has been to establish removal rates of major cations in meltwaters and to define chemical denudation rates. Despite temperature-dependence effects on the rate of dissolution (Drever and Zobrist, 1992; Velbel, 1993), such studies indicate rates of chemical erosion in glaciated catchments which are 1.2-2.6 times the continental average (Sharp and others, 1995). The efficacy of chemical weathering in glacial environments is attributable to high flushing rates, turbulent meltwaters, high suspended-sediment concentrations and the low buffering capacity of dilute meltwaters Sharp and others, 1995). However, few studies have attempted to disaggregate the solute load of glacial runoff into crustal, atmospheric and snowpack sources (cf. Sharp and others, 1995), and to identify variations in solute sources and chemical weathering mechanisms on a seasonal time-scale (Tranter and others, 1993; Brown and others, 1994).

This paper analyzes the provenance of solute in the proglacial stream draining Haut Glacier d'Arolla during most of the 1989 ablation season, utilising meltwaterquality data derived from twice-daily sampling. Dissolved species are partitioned into components derived from sea salt, acid aerosol, dissolution of atmospheric $\mathrm{CO}_{2}$, and lithogenic sources, namely carbonates, sulphides and aluminosilicates. Variations in solute provenance are then related to the seasonal evolution of the subglacial hydrological system.

\section{FIELD SITE}

Sampling was undertaken at Haut Glacier d'Arolla, the most southerly glacier in the Val d'Hérens, Valais, Switzerland. The glacier has an altitudinal range of $\sim 2560-3500 \mathrm{~m}$, and occupies approximately $6.3 \mathrm{~km}^{2}$ of a 
$12 \mathrm{~km}^{2}$ catchment. The maximum length of the glacier is approximately $4.2 \mathrm{~km}$. A number of portals $(2-5)$ contribute meltwater to the bulk runoff (Sharp and others, 1993). The bedrock geology is varied and consists of metamorphic and igneous rocks of the Arolla series of the Dent Blanche nappe, the highest tectonic unit of the Valais Alps (Dal Piaz and others, 1977; Mazurek, 1986). Geochemically reactive minerals, such as pyrite and calcite (Table 1), have been identified by microscopy and are present in trace amounts in many of the rocks throughout the catchment (Brown, 1991). In addition, XRD data from the main lithological units indicate that the main feldspars are albite, anorthite, microcline and sanidine, the main olivines are diopside, enstatite and spodumene. Actinolite, muscovite, corderite, hematite, hydrobasaluminite, quartz and talc are also present (personal communication from D. Webb, cited in Tranter and others, in press).

\section{METHODS AND TECHNIQUES}

Bulk meltwaters were sampled $\sim 100 \mathrm{~m}$ from the glacier snout twice daily at 1000 and $1700 \mathrm{~h}$ local time (approximating to minimum and maximum diurnal discharge, respectively), from 1 June (Julian day 152) to 31 August 1989 (Julian day 243). The samples were immediately vacuum filtered through $0.45 \mu \mathrm{m}$ cellulose nitrate membranes, and stored in pre-cleaned plastic bottles. Total alkalinity was determined colorimetrically in a field laboratory to an end-point of $\mathrm{pH} 4.5$ using $\mathrm{BDH}$ mixed indicator solution and $1 \mathrm{mmol} \mathrm{HCl}$.
Precision was $\pm 2 \%$. The concentration of $\mathrm{HCO}_{3}{ }^{-}$was determined from the total alkalinity by correcting for acid needed to acidify a volume of deionised water equal to the volume of the aliquot and the titre. The major cations $\left(\mathrm{Ca}^{2+}, \mathrm{Mg}^{2+}, \mathrm{Na}^{+}, \mathrm{K}^{+}\right)$were determined by AAS, using an air-acetylene flame. Spectrochemical buffers, $\mathrm{La}\left(\mathrm{NO}_{3}\right)_{3}$ and $\mathrm{CsCl}$, were added to overcome chemical interferences and ionisation, respectively. Accuracy was $\pm 5 \%$. Major anions $\left(\mathrm{Cl}^{-}, \mathrm{NO}_{3}{ }^{-}, \mathrm{SO}_{4}{ }^{2-}\right)$ were determined by ion chromatography on a Dionex 4000 i. Accuracy was $\pm 3 \%$.

Bulk meltwater dissolved-ion concentrations were separated into crustal, sea-salt and snowpack derived components, as detailed in Sharp and others (1995). All $\mathrm{NO}_{3}{ }^{-}$and $\mathrm{Cl}^{-}$was assumed to be atmospherically derived, with sea-salt contributions of $\mathrm{Ca}^{2+}, \mathrm{Mg}^{2+}$, $\mathrm{Na}^{+}, \mathrm{K}^{+}$and $\mathrm{SO}_{4}{ }^{2}$ derived from standard sea-water ratios with $\mathrm{Cl}^{-}$(Holland, 1978). Atmospherically derived $\mathrm{SO}_{4}{ }^{2-}$ associated with acid sulphate aerosols was calculated from the average $\mathrm{Cl}^{-}: \mathrm{SO}_{4}{ }^{2}$ ratio measured in the $1992 / 93$ winter snowpack (0.4107). Since the early stages of aluminosilicate dissolution are non-stoichiometric (see Lerman, 1979), atmospheric $\mathrm{HCO}_{3}{ }^{-}$derived from the carbonation of aluminosilicates was estimated from the sum of ${ }^{*} \mathrm{Na}^{+}$and ${ }^{*} \mathrm{~K}{ }^{+}$(where ${ }^{*}$ denotes nonsea-salt sodium and potassium) rather than from a ratio with silica (although carbonation of aluminosilicates probably also contributes to the fluxes of $\mathrm{Ca}^{2+}$ and $\left.\mathrm{Mg}^{2+}\right)$. Therefore, this represents the lower limit for $\mathrm{CO}_{2}$ drawdown associated with the carbonation of aluminosilicates. Coupled sulphide oxidation and carbonate dissolution $(\mathrm{SO} / \mathrm{CD})$ generates all the crustally derived

Table 1 . Mineralogical composition (\%) of fine material $(<5 \mathrm{~mm})$ from sampling locations $A-I$ on the medial moraines of Haut Glacier d'Arolla (data from Brown, 1991)

\begin{tabular}{|c|c|c|c|c|c|c|c|c|c|}
\hline & $A$ & $B$ & $C$ & $D$ & $E$ & $F$ & $G$ & $H$ & $I$ \\
\hline \multicolumn{10}{|l|}{ Carbonates: } \\
\hline Calcite & 5.67 & 11.45 & 0.00 & 0.00 & 0.42 & 3.55 & 1.35 & 0.00 & 0.41 \\
\hline \multicolumn{10}{|l|}{ Silicates: } \\
\hline Quartz & 27.53 & 39.02 & 58.48 & 66.40 & 64.35 & 42.55 & 55.61 & 66.75 & 60.94 \\
\hline Orthoclase & 0.00 & 0.23 & 0.00 & 0.00 & 0.00 & 0.00 & 0.00 & 0.25 & 0.00 \\
\hline Microcline & 0.61 & 0.00 & 0.00 & 0.60 & 0.63 & 0.00 & 0.90 & 2.25 & 0.00 \\
\hline Plagioclase & 0.40 & 0.00 & 0.39 & 0.20 & 0.00 & 1.18 & 0.22 & 2.00 & 2.25 \\
\hline Perthite & 0.61 & 0.00 & 0.78 & 0.40 & 0.63 & 0.95 & 1.35 & 0.00 & 0.82 \\
\hline Tremolite-actinolite & 8.70 & 2.57 & 0.78 & 3.02 & 2.53 & 0.71 & 0.00 & 0.50 & 1.23 \\
\hline Hornblende & 0.20 & 0.00 & 0.00 & 0.80 & 0.42 & 0.24 & 0.00 & 0.00 & 1.43 \\
\hline Amphibole (misc.) & 4.86 & 2.10 & 1.56 & 5.84 & 5.49 & 3.31 & 1.57 & 0.50 & 2.66 \\
\hline Sphene & 0.40 & 3.04 & 0.00 & 0.00 & 0.00 & 0.00 & 0.00 & 0.00 & 0.00 \\
\hline Zoisite & 4.25 & 7.24 & 2.92 & 0.20 & 0.21 & 0.71 & 1.79 & 1.50 & 0.81 \\
\hline Epidote & 1.21 & 0.93 & 0.39 & 2.82 & 0.42 & 0.00 & 0.00 & 0.50 & 4.50 \\
\hline Muscovite & 13.97 & 16.59 & 26.51 & 12.07 & 11.39 & 18.68 & 21.08 & 10.75 & 15.13 \\
\hline Biotite & 10.93 & 3.97 & 1.75 & 0.20 & 0.42 & 5.44 & 0.45 & 1.00 & 0.00 \\
\hline Mica (misc.) & 10.53 & 4.67 & 3.51 & 2.41 & 1.69 & 8.27 & 9.87 & 7.00 & 2.25 \\
\hline Chlorite & 7.29 & 5.61 & 1.17 & 3.62 & 6.96 & 9.22 & 4.48 & 3.25 & 6.75 \\
\hline \multicolumn{10}{|l|}{ Opaques: } \\
\hline Mainly pyrite & 3.24 & 2.10 & 1.56 & 1.21 & 1.05 & 4.96 & 1.35 & 2.75 & 0.82 \\
\hline Others & 0.00 & 0.47 & 0.19 & 0.20 & 2.95 & 0.24 & 0.00 & 2.75 & 0.00 \\
\hline Total & 100.40 & 99.99 & 99.99 & 99.99 & 99.56 & 100.01 & 100.02 & 100.00 & 100.00 \\
\hline
\end{tabular}


$\mathrm{SO}_{4}{ }^{2-}$, yielding one equivalent of $\mathrm{HCO}_{3}$ and two equivalents of $\mathrm{Ca}^{2+}+\mathrm{Mg}^{2+}$. Snowpack acidity from acid sulphate and nitrate aerosols was assumed to weather carbonate minerals to produce crustally derived $\mathrm{HCO}_{3}^{-}$. The residual $\mathrm{HCO}_{3}$ was assumed to arise equally from the dissolution and dissociation of atmospheric $\mathrm{CO}_{2}$ and the carbonation of carbonate minerals, which produced all the crustally derived non-SO/CD $\mathrm{Ca}^{2+}$ and $\mathrm{Mg}^{2+}$.

\section{RESULTS AND DISCUSSION}

Figure 1 shows the discharge and suspended-sediment concentration records for much of the 1989 ablation season (Brown and others, 1994). Discharge and discharge amplitude increased as the season progressed, accompanied by an increase in suspended-sediment concentration, reflecting the seasonal evolution of the drainage system (Brown and others, 1994).

The subglacial hydrological system of Alpine glaciers appears to be adequately described by two principal flow components Collins, 1978; Oerter and others, 1980; Tranter and Raiswell, 1991). Quick-flow waters are derived largely from icemelt, and pass rapidly through a channelised hydrological system of ice-walled channels and major arterial conduits (Sharp, 1991; Brown and others, 1994). Conversely, delayed-flow waters are derived largely from snowmelt, and pass more slowly through a
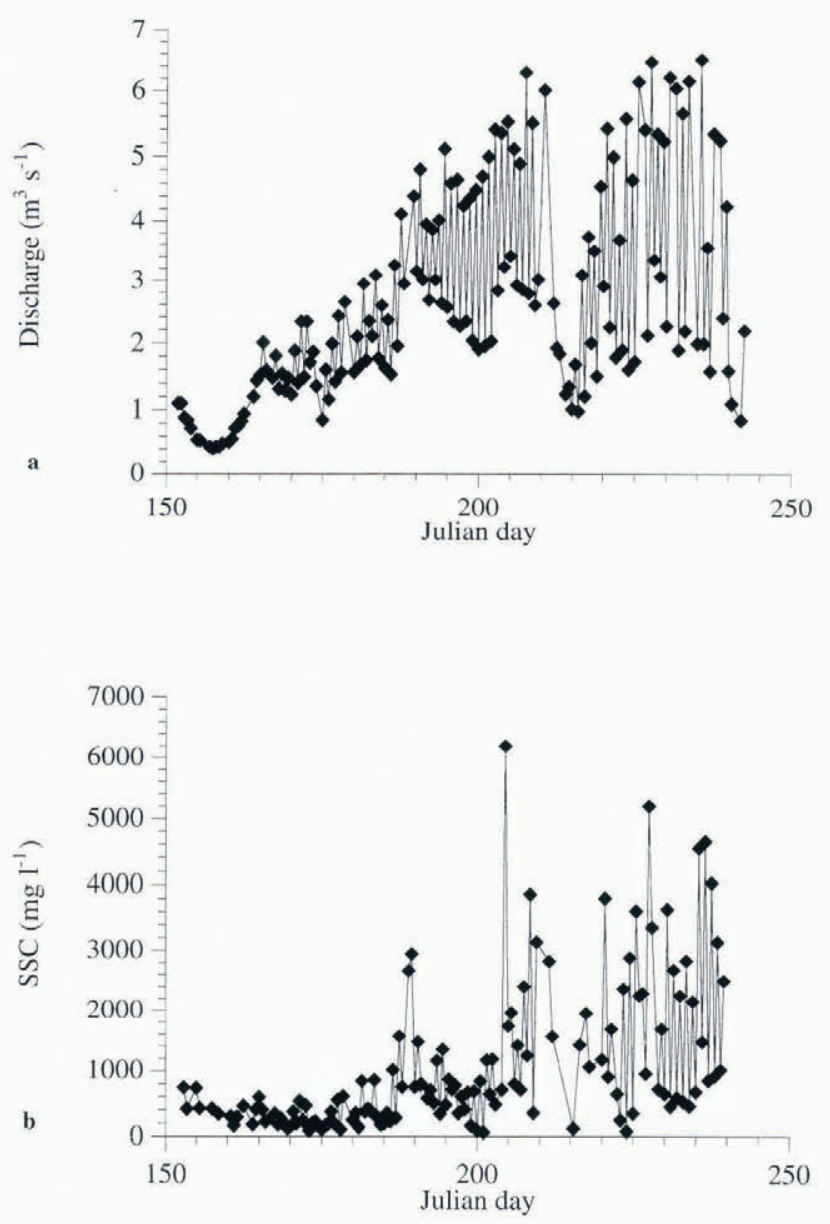

Fig. 1. Variability in mellwater discharge and suspendedsediment concentration in bulk runoff from Haut Glacier d'Arolla during the 1989 ablation season. distributed hydrological system e.g. linked, water-filled cavities (Walder, 1986)). These two components mix to form bulk meltwaters draining the glacier, with the channelised system expanding headwards at the expense of the distributed system as the melt season progresses Brown and others, 1994).

\section{Sources of aqueous protons}

Chemical erosion by Alpine glacial meltwaters is predominantly by the broad class of reactions known as acid hydrolysis (Tranter and others, 1993). Raiswell (1984) has suggested that the anionic content of glacial meltwaters demonstrates the acid source used in the chemical weathering of rock minerals. $\mathrm{HCO}_{3}$ is the dominant anion where the dissolution and dissociation of atmospheric $\mathrm{CO}_{2}$ provides protons to fuel chemical erosion (Equations (1) and (2)).

$$
\begin{aligned}
& \mathrm{CaCO}_{3}(\mathrm{~s})+\mathrm{CO}_{2}(\mathrm{aq})+\mathrm{H}_{2} \mathrm{O}(\mathrm{aq}) \\
& \text { calcite } \rightleftharpoons \mathrm{Ca}^{2+}(\mathrm{aq})+2 \mathrm{HCO}_{3}^{-}(\mathrm{aq}) \\
& \mathrm{CaAl}_{2} \mathrm{Si}_{2} \mathrm{O}_{8}(\mathrm{~s})+2 \mathrm{CO}_{2}(\mathrm{aq})+2 \mathrm{H}_{2} \mathrm{O}(\mathrm{aq}) \\
& \rightleftharpoons \mathrm{Ca}^{2+}(\mathrm{aq})+2 \mathrm{HCO}_{3}^{-}(\mathrm{aq})+\mathrm{H}_{2} \mathrm{Al}_{2} \mathrm{Si}_{2} \mathrm{O}_{8}(\mathrm{~s}) \\
& \text { partially weathered feldspar (2) }
\end{aligned}
$$

Conversely, $\mathrm{SO}_{4}{ }^{2-}$ is the dominant anion where protons are derived from the oxidation of sulphide minerals Equation (3)).

$$
\begin{gathered}
4 \mathrm{FeS}_{2}(\mathrm{~s})+15 \mathrm{O}_{2}(\mathrm{aq})+14 \mathrm{H}_{2} \mathrm{O}(\mathrm{aq}) \\
\rightleftharpoons 16 \mathrm{H}^{+}(\mathrm{aq})+4 \mathrm{Fe}(\mathrm{OH})_{3}(\mathrm{~s})+8 \mathrm{SO}_{4}{ }^{2-}(\mathrm{aq} \\
\text { ferric oxyhydroxides }
\end{gathered}
$$

Typically, chemical reactions are coupled, such that solute acquisition in glacial meltwaters involves species in solid, liquid and aqueous phases Tranter and others, 1993), e.g.

$$
\begin{array}{r}
4 \mathrm{FeS}_{2}(\mathrm{~s})+16 \mathrm{CaCO}_{3}(\mathrm{~s})+15 \mathrm{O}_{2}(\mathrm{aq})+14 \mathrm{H}_{2} \mathrm{O}(\mathrm{aq}) \rightleftharpoons \\
\left.16 \mathrm{Ca}^{2+}(\mathrm{aq})+16 \mathrm{HCO}_{3}(\mathrm{aq})+8 \mathrm{SO}_{4}^{2}(\mathrm{aq})+4 \mathrm{Fe} \mathrm{OH}\right)_{3}(\mathrm{~s}) \\
\text { ferric oxyhydroxides }
\end{array}
$$

Therefore, the proportion of $\mathrm{HCO}_{3}$ and $\mathrm{SO}_{4}{ }^{2}$ in the bulk meltwaters will reflect the relative dominance of the two major sources of protons driving subglacial chemical erosion (Fig. 2). Expressed as the ratio of $\mathrm{HCO}_{3}$ to $\left.\mathrm{HCO}_{3}+\mathrm{SO}_{4}{ }^{2}\right)$, a ratio of 1.0 would signify carbonation reactions involving pure dissolution and acid hydrolysis, consuming protons derived from atmospheric $\mathrm{CO}_{2}$ Equations (1) and (2)). Conversely, a ratio of 0.5 suggests coupled reactions involving the weathering of carbonates by protons derived from sulphide oxidation (Equation (4)).

It is clear from Figure 2 that when flow from the distributed system, which underlies the whole glacier in early June (Brown and others, 1994), dominates bulk discharge early in the ablation season, the ratio of $\mathrm{HCO}_{3}{ }^{-} /\left(\mathrm{HCO}_{3}+\mathrm{SO}_{4}{ }^{2}\right)$ (hereafter the C-ratio) $(\sim 0.65)$ suggests that coupled reactions, involving carbonate dissolution and protons derived primarily (though not exclusively) from the oxidation of sulphide minerals, largely control bulk meltwater composition. It 


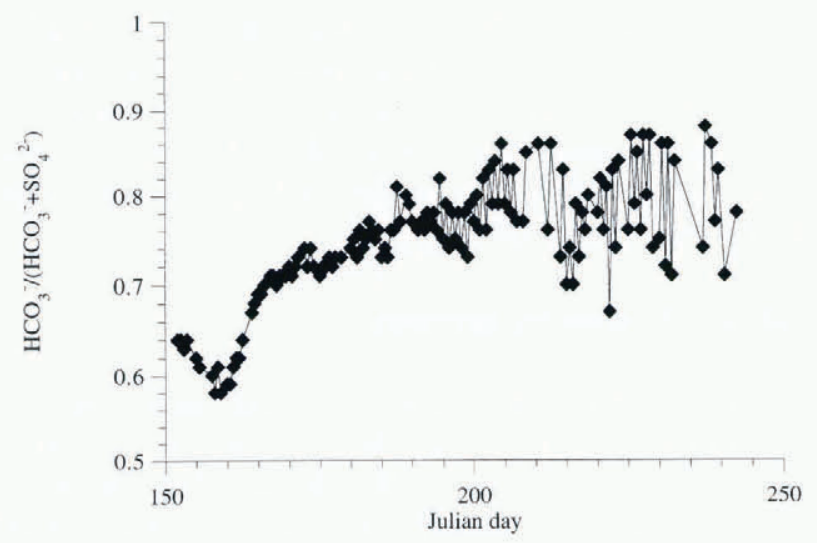

Fig. 2. Variability in the ratio of $\mathrm{HCO}_{3}^{-} /\left(\mathrm{HCO}_{3}{ }^{-}+\mathrm{SO}_{4}{ }^{2}\right)$ in bulk meltwaters draining Haut Glacier d'Arolla over the 1989 ablation season.

is unlikely that a system of linked cavities (Walder, 1986) is in intimate contact with a large source of atmospheric $\mathrm{CO}_{2}$ to enhance the C-ratio to $>0.5$ (Tranter and others, 1993). Other possible sources of $\mathrm{CO}_{2}(\mathrm{aq})$ in the distributed system may include $\mathrm{HCO}_{3}$ in meltwaters feeding the distributed system, the release of bubbles trapped in basal ice facies (Tison and others, 1993; Tranter and others, in press), microbial oxidation of organic carbon (Tranter and others, in press) and the oxidation of elemental free carbon. Carbon occurs both as a combined form (mainly as carbonates of $\mathrm{Ca}^{2+}$ and $\mathrm{Mg}^{2+}$ ) and as a free element (e.g. diamond and graphite) in addition to that associated with $\mathrm{CO}_{2}$ (Greenwood and Earnshaw, 1984). Graphite is widely distributed, associated with quartz and metamorphosed sedimentary silicate rocks such as mica-schists and gneisses all of which are present in the Haut Glacier d'Arolla catchment (Brown, 1991). Indeed, this recycling of carbon from sediments to fresh waters via rock weathering forms an integral part of the global carbon cycle (e.g. Holland, 1978; Stumm and Morgan, 1981). The importance of these coupled reactions in controlling meltwater composition in the delayed-flow component is also evident to a lesser extent in the C-ratio $(<0.75)$ during the major recession flow event at the end of July (Julian day 212) when snow fell on the glacier surface, reducing surficial meltwater inputs to the hydroglacial system, resulting in delayed flow waters forming an increasing proportion of the bulk runoff), and in the diurnal variability from midJuly onwards when the C-ratio is lower at daily minimum discharge. Conversely, when the quick-flow component dominates maximum diurnal bulk meltwater discharge from mid-July onwards (Brown and others, 1994), the Cratio (0.75-0.9) suggests protons are derived primarily from the dissolution and dissociation of atmospheric $\mathrm{CO}_{2}$.

Protons to fuel chemical erosion may also be derived from the dissolution of acid sulphate and nitrate aerosols in the seasonal snowpack (Tranter and others, 1993). Significant contributions from this source of acidity are limited to the early melt season (Fig. 3), as a result of fractionation processes within the snowpack (Johannessen and Henriksen, 1978) and the up-glacier retreat of the seasonal snow cover as the ablation season proceeds (Tranter and others, 1993).

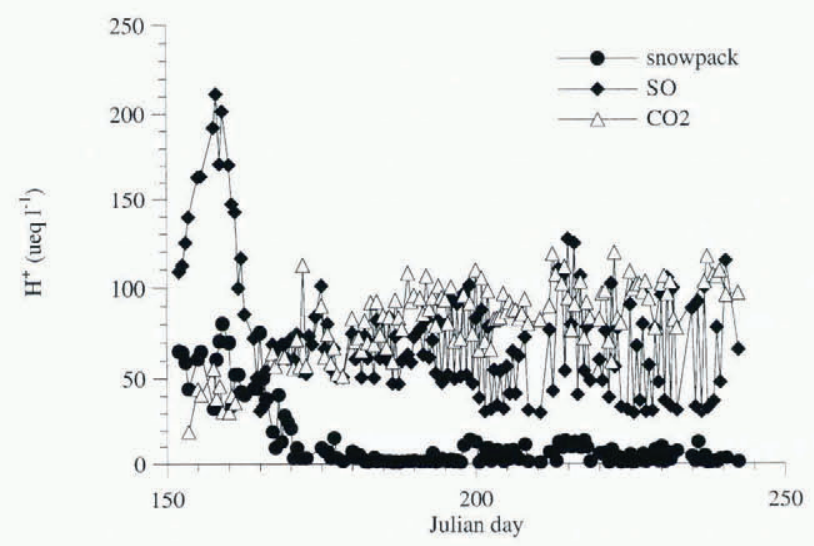

Fig. 3. Sources of protons (snowpack (acid nitrate and sulphate aerosols)), $\mathrm{SO}$ (sulphide oxidation) and $\mathrm{CO}_{2}$ (carbonic acid) driving chemical weathering during the 1989 ablation season.

\section{Lithogenic solute provenance}

Contributions of solute from various rock types are often calculated by assuming that their contribution is proportional to their mass (Garrels and Mackenzie, 1971). However, minerals weather at different rates, and examples of such weathering sequences are common in the geochemical literature (e.g. Goldich, 1938; Stumm and Morgan, 1981). Therefore, the relative abundance and reactivity of available minerals within a catchment will affect the degree and nature of chemical erosion. Using $\mathrm{HCO}_{3}{ }^{-}$as an indicator of the relative proportions of solute contributed by lithogenic coupled $\mathrm{SO} / \mathrm{CD}$ erosion, dissolution of carbonates by acidity derived from the snowpack $(\mathrm{SP} / \mathrm{CD})$ and carbonation of carbonates $(\mathrm{C} / \mathrm{CD})$ ) and atmospheric (carbonation of aluminosilicates and carbonates) sources (Fig. 4), the calculations detailed above suggest that the weathering of carbonates supplies the vastly greater part of the $\mathrm{HCO}_{3}{ }^{-}$in solution. This is in direct contrast to the actual percentage of carbonate within the bedrock, which from samples of fines $(<5 \mathrm{~mm}$ diameter) from supraglacial moraines is $<12 \%$, and generally $<5 \%$ (Table 1; Brown, 1991). While the total contribution from carbonate minerals is in excess of $85 \%$, the proportion of solute acquired from carbonation of carbonates and $\mathrm{SO} / \mathrm{CD}$ reactions, and the wealhering mechanisms producing the solute, change as the ablation season progresses. This is clearly illustrated in Figure 4, and will be discussed in more detail in the following paragraphs, where we discuss solute provenance from the major lithogenic sources.

\section{(i) Carbonation of carbonates}

The stoichiometry of Equation (1) suggests that the proportion of the $\mathrm{HCO}_{3}$ load derived from lithogenic and atmospheric sources is equal in equivalence units. If it is assumed that acidity derived from the seasonal snowpack (Fig. 3) is predominantly neutralised by the weathering of carbonates during the early melt season (based on the idea that most solute appears to come from the weathering of lithogenic carbonates; Sharp and others, 1995), this augments the levels of early-season $\mathrm{HCO}_{3}$ derived from the carbonation of carbonates, resulting in a relatively constant contribution of litho- 

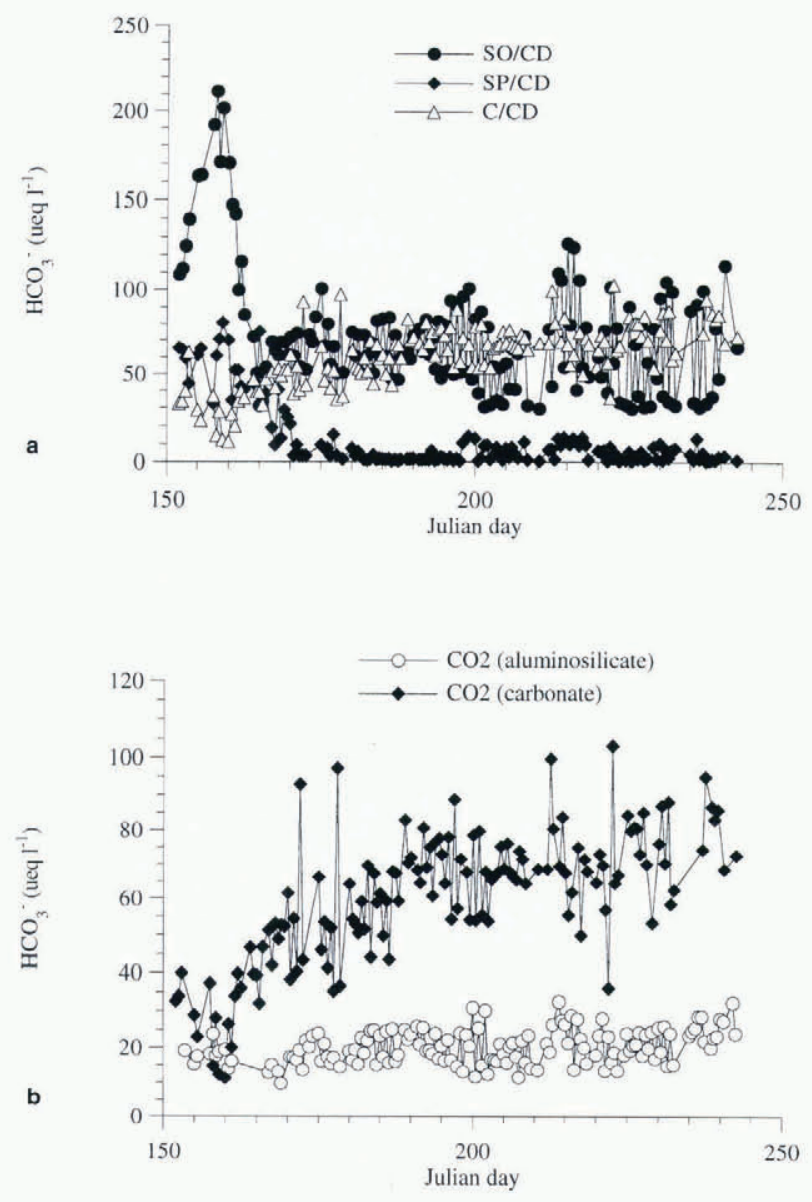

Fig. 4. $\mathrm{HCO}_{3}$ provenance in bulk runoff during the 1989 ablation season. Crustal $\mathrm{HCO}_{3}(a)$ is derived from coupled sulphide oxidation and carbonate dissolution $(S O / C D)$, dissolution of carbonates by snowpack acidity (SP/CD) and carbonation of carbonate minerals (C/CD). Atmospheric $\mathrm{HCO}_{3}^{-}(b)$ is derived from the dissolution and dissociation of atmospheric $\mathrm{CO}_{2}$ associated with the hydrolytic wealhering of aluminosilicate and carbonate minerals.

genic $\mathrm{HCO}_{3}$ throughout the entire ablation season (Fig. $5 \mathrm{a}$. This is in direct contrast to the proportion of $\mathrm{HCO}_{3}$ derived from the dissolution and dissociation of atmospheric $\mathrm{CO}_{2}$ (Fig. 5b), which shows a steady increase as the ablation season proceeds, reflecting the headwards expansion of the channelised system, the increasing proportion of quick-flow waters in runoff, and increasing suspended-sediment concentrations.

\section{(ii) Coupled sulphide oxidation and carbonate dissolution}

Recent models of solute acquisition beneath Alpine glaciers suggest that chemical erosion in the distributed system is dominated by coupled sulphide oxidation and carbonate dissolution (Tranter and others, 1993, in press; Brown and others, 1994; Equation (4)). This is confirmed in the provenance calculations, which illustrate a peak in $\mathrm{HCO}_{3}(\mathrm{SO} / \mathrm{CD}), \mathrm{SO}_{4}{ }^{2}$ (crustal) and $\mathrm{Ca}^{2+}+\mathrm{Mg}^{2+}$ SO/CD) during the early part of the ablation season (Julian days 152-165), when delayed flow waters dominate runoff (Fig. 6). The role of $\mathrm{SO} / \mathrm{CD}$ reactions in the distributed system is also evident to a lesser extent during the recession flow event at the end of July (Julian days 212-220).
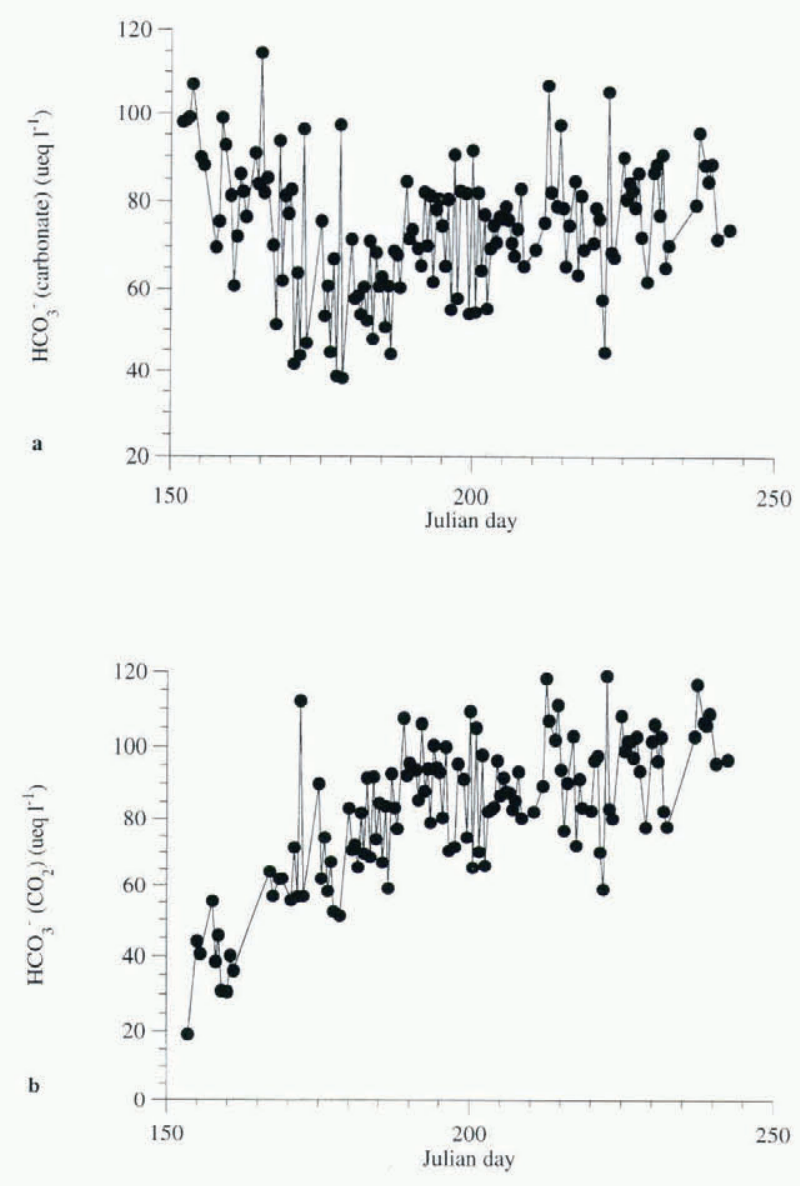

Fig. 5. $\mathrm{HCO}_{3}^{-}$derived from (a) the carbonation of carbonates $(C / C D+S P / C D)$ and $(b)$ the dissolution and dissociation of atmospheric $\mathrm{CO}_{2}$ during the 1989 ablation season.

\section{(iii) Carbonation of aluminosilicates}

Relative to the carbonation of carbonate minerals, the weathering of aluminosilicates by carbonation reactions remains relatively constant during the ablation season (Fig. 4b), exhibiting only a slight increase as the melt season progresses. This is illustrated (Fig. 7a) by variations in atmospherically derived $\mathrm{HCO}_{3}$ associated with the carbonation of aluminosilicates. ${ }^{*} \mathrm{Na}^{+}$shows a monotonic increase as the ablation season progresses, associated with increased weathering of plagioclase- and sodic-feldspars (Fig. 7b). Following an early-season peak, ${ }^{*} \mathrm{~K}^{+}$also increases, especially during August, associated with increased weathering of biotite, muscovite and potash-feldspar (Fig. 7c). This suggests that part of the increasing proportion of solute derived from carbonation reactions between dilute quick-flow waters and suspended sediment is derived from aluminosilicate minerals in suspension as the ablation season progresses (Fig. 4; Brown and others, 1994).

\section{CONGLUSIONS}

To date, few studies have attempted to disaggregate the solute load of glacial runoff into crustal, atmospheric and snowpack sources, and to identify variations in solute sources and weathering mechanisms on a seasonal timescale. Therefore, snowpack-derived solute is usually 

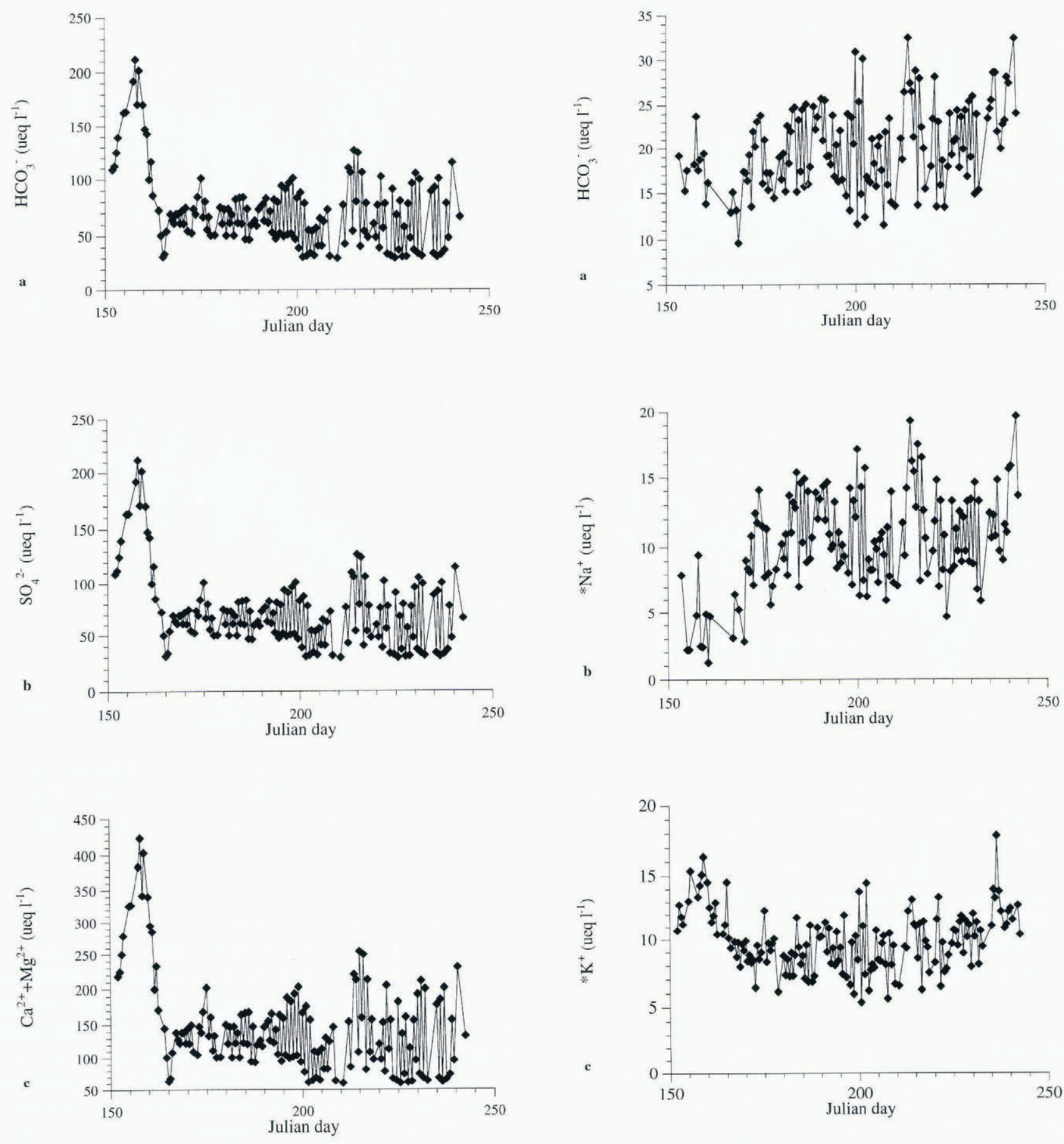

Fig. 6. Bulk meltwater concentrations of (a) $\mathrm{HCO}_{3}{ }^{-}$ ( $\mathrm{SO} / \mathrm{CD}$ (crustal)), (b) $\mathrm{SO}_{4}^{2-}$ and (c) $\mathrm{Ca}^{2+}+$ $\mathrm{Mg}^{2+}$ associated with coupled $S O / C D$ reactions during the 1989 ablation season.

incorporated in estimates of chemical denudation rates in glacial catchments (Sharp and others, 1995). When dissolved species are partitioned into components derived from sea salt, acid aerosol, dissolution of atmospheric $\mathrm{CO}_{2}$ and lithogenic sources, seasonal changes in solute provenance and in the dominant chemical weathering process are observed.

Trace geochemically reactive minerals in the bedrock (e.g. carbonate and sulphide minerals) appear to contribute the major proportion of solute found in bulk runoff. The major anions are bicarbonate and sulphate, suggesting that two primary sources of protons are utilised to fuel the chemical erosion of glacial sediments: (i) sulphide oxidation, and (ii) the dissolution and dissociation of atmospheric $\mathrm{CO}_{2}$. Solute contributions from the seasonal snowpack are limited to the early melt season, accompanied by a transient weathering of crustal material associated with snowpack acidity.

Whereas the chemical weathering of aluminosilicate minerals by carbonation reactions supplies a relatively constant proportion of bulk meltwater solutes during the ablation season, the chemical erosion of carbonates shows distinct scasonal variations in the proportion supplied, reflecting changes in the nature of the subglacial drainage system. There are two subglacial environments in which carbonates are chemically eroded, the distributed and 
channelised drainage systems. Chemical weathering of carbonates in the distributed system is driven by protons derived from the oxidation of sulphide minerals. This peaks early in the ablation season and is relatively constant thereafter, reflecting the reduction in areal extent of the distributed system, and hence the proportion of delayed flow waters in the bulk discharge. In contrast, carbonation of carbonates is the dominant weathering process in quick-flow waters where there is usually free access to atmospheric $\mathrm{CO}_{2}$. The magnitude of carbonation increases as the channelised drainage system grows throughout the ablation season, accompanied by an increase in the proportion of quick-flow waters and suspended-sediment concentrations in bulk runoff. In addition, carbonation of the aluminosilicate fraction of the suspended-sediment load also increases, reflected in the proportion of atmospheric $\mathrm{HCO}_{3}{ }^{-}$derived from the carbonation of aluminosilicates, ${ }^{*} \mathrm{Na}^{+}$and ${ }^{*} \mathrm{~K}$. Therefore, the seasonal evolution of the subglacial drainage system plays an important role in determining both the source of solute and the weathering mechanism driving chemical erosion.

The chemical weathering of carbonates is enhanced during the early melt season by acidic snowmelt. The decrease in this mechanism of chemical weathering through the ablation season is offset by the increase in chemical weathering in the channelised drainage system driven by carbonation reactions. We conclude that subglacial drainage structure and the relative abundance and reactivity of available minerals within the catchment are key controls on the extent of subglacial chemical weathering.

\section{ACKNOWLEDGEMENTS}

This work was supported by a U.K. Natural Environment Research Council Studentship (GT4/88/AAPS/56) and Fellowship (GT5/F/91/AAPS/3) to G.H.B. and by NERC Grants GR3/7004a and GR3/8114. The Royal Society and University of Wales Learned Societies Fund provided financial support to attend the conference in Reykjavík. Dr A. Barker is gratefully acknowledged for his contributions to the derivation of the lithological data in the Department of Geology, University of Southampton. C. Hill provided invaluable assistance in the field.

\section{REFERENGES}

Brown, G. H. 1991. Solute provenance and transport pathways in Alpine glacial environments. (Ph.D. thesis, University of Southampton.

Brown, G.H., M.J. Sharp, M. Tranter, A. M. Gurnell and P.W. Nienow. 1994. Impact of post-mixing chemical reactions on the major ion chemistry of bulk meltwaters draining the Haut Glacier d'Arolla, Valais, Switzerland. Hydrological Processes, 8 5), 465-480.

Brown, G.H., M. Tranter and M.J. Sharp. In press. Experimental investigations of solute acquisition from suspended sediment by Alpine glacial meltwaters. Hydrological Processes.

Collins, D. N. 1978. Hydrology of an alpine glacier as indicated by the chemical composition of meltwater. Z. Gletscherkd. Glazialgeol., 13 12), 1977, 219-238.

Dal Piaz, G. V., G.P. de Vecchi and J. Hunziker. 1977. The Austroalpine layered gabbros of the Matterhorn and Mont CollonDents de Bertol. Schweiz. Mineral. Petrogr. Milt. 57, 5981.

Drever, J. I. and J. Zobrist. 1992. Chemical weathering of silicate rocks as a function of elevation in the southern Swiss Alps. Geochim. Cosmochim. Acta, 56, 3209-3216.

Garrels, R. M. and F. T. Mackenzie. 1971. Evolution of sedimentary rocks. New York, W. W. Norton.

Goldich, S. S. 1938. A study in rock weathering. 7. Geol., 46, 17-58.

Greenwood, N. N. and A. Earnshaw. 1984. Chemistry of the elements. Oxford, Pergamon.

Holland, H. D. 1978. The chemistry of the atmosphere and oceans. New York, etc., John Wiley and Sons.

Johannessen, M. and A. Henriksen. 1978. Chemistry of snow meltwater: changes in concentration during melting. Water Resour. Res., 14 4), $615-619$.

Lerman, A. 1979. Geochemical processes: water and sediment emironments. New York, etc., John Wiley and Sons.

Livingstone, D. A. 1963. Chemical composition of rivers and lakes. U.S. Geol. Surv. Prof. Pap. 400G.

Mazurek, M. 1986. Structural evolution and metamorphism of the Dent Blanche nappe and the Combin zone west of Zermatt (Switzerland). Eclogae Geol. Helv., 79 1), 41-56.

Oerter, H., H. Behrens, G. Hibsch, W. Rauert and W. Stichler. 1980. Combined environmental isotope and electrical conductivity investigations of the runoff of Vernagtferner (Oetztal Alps). Mater. Glyatsiol. Issled. 39, 86 91, 157-161.

Raiswell, R. 1984. Chemical models of solute acquisition in glacial melt waters. J. Glaciol., 30 (104), 49-57.

Reynolds, R. C., Jr and N. M. Johnson. 1972. Chemical weathering in the temperate glacial environment of the Northern Cascade Mountains. Geochim. Cosmochim. Acta, 36, 537-554.

Sasseville, D. R., N. Eyles, R.M. Slatt and R.J. Rogerson. 1977. Chemical transport mechanisms in an actively glaciated basin, British Columbia. Geol. Soc. Am. Abstr. Programs, 9 7), 1156

Sharp, M.J. 1991. Hydrological influences from meltwater quality data: the unfulfilled potential. Proceedings, 3rd National Hydrological Symposium, 16-18 September 1991, Southampton. British Hydrological Society, 5.1-5.8.

Sharp, M. J. and 6 others. 1993. Geometry, bed topography and drainage system structure of the Haut Glacier d'Arolla, Switzerland. Earth Surface Processes and Landforms, 18 6), 557-571.

Sharp, M., M. Tranter, G. H. Brown and M. Skidmore. 1995. Rate of chemical denudation and $\mathrm{CO}_{2}$ draw-down in a glacier-covered Alpine catchment. Geology, 23 1), 61-64.

Stumm, W. and J.J. Morgan. 1981. Aquatic chemistry: an introduction emphasizing chemical equilibria in natural waters. Second edition. New York. etc., John Wiley and Sons.

Tison, J.-L., J. -R. Petit, J. -M. Barnola and W. C. Mahanev. 1993. Debris entrainment at the ice bedrock interface in sub-freczing temperature conditions (Terre Adélie, Antarctica). J. Glaciol. 39 132), 303-315.

Tranter, M. and R. Raiswell. 1991. The composition of the englacial and subglacial component in bulk meltwaters draining the Gornergletscher, Switzerland. 7. Glaciol., 37 125), 59-66.

Tranter, M., G. Brown, R. Raiswell, M. Sharp and A. Gurnell. 1993. A conceptual model of solute acquisition by Alpine glacial meltwaters. J. Glaciol., 39 133), $573-581$.

Tranter, M. and 9 others. In press. Variability in the chemical composition of in situ subglacial meltwaters. Hydrological Processes.

Velbel, M. A. 1993. Temperature dependence of silicate weathering in nature: how strong a negative feedback on long-term accumulation of atmospheric $\mathrm{CO}_{2}$ and global greenhouse warming? Geology, 21, 1059-1062.

Walder, J.S. 1986. Hydraulics of subglacial cavities. F. Glaciol., 32112 , $439-445$. 